\title{
6-OHDA-Induced Changes in Parkinson's Disease-Related Gene Expression are not Affected by the Overexpression of PGAM5 in In Vitro Differentiated Embryonic Mesencephalic Cells
}

\author{
Tomasz Maciej Stępkowski ${ }^{1}$ Iwona Wasyk ${ }^{1} \cdot$ Agnieszka Grzelak $^{2}$ • \\ Marcin Kruszewski ${ }^{1,3,4}$
}

Received: 17 February 2015/Accepted: 5 May 2015/Published online: 19 May 2015

(c) The Author(s) 2015. This article is published with open access at Springerlink.com

\begin{abstract}
LUHMES cells, a recently established line of immortalized embryonic mesencephalic cells, are the novel in vitro model for studying Parkinson's disease (PD) and dopaminergic neuron biology. Phosphoglyceromutase 5 (PGAM5) is a mitochondrial protein involved in mitophagy, mitochondria dynamics, and other processes important for PD pathogenesis. We tested the impact of lentiviral overexpression of PGAM5 protein in LUHMES cells on their differentiation and expression of 84 PD-related genes. LUHMES cells were transduced with PGAM5 or mock and treated with $100 \mu \mathrm{M}$ 6-hydroxydopamine (6OHDA), a model PD neurotoxin. Real-Time PCR analysis revealed that the treatment with 6-OHDA-induced changes in expression of 44 PD-related genes. PGAM5 transduction alone did not cause alternations in PD-related genes expression, nor it affected changes in gene expression mediated by 6-OHDA. The 6-OHDA-induced PD-related gene
\end{abstract}

Electronic supplementary material The online version of this article (doi:10.1007/s10571-015-0207-5) contains supplementary material, which is available to authorized users.

Tomasz Maciej Stępkowski

t.stepkowski@ichtj.waw.pl

1 Centre for Radiobiology and Biological Dosimetry, Institute of Nuclear Chemistry and Technology, Dorodna 16, 03-195 Warsaw, Poland

2 Department of Molecular Biophysics, University of Łódź, Banacha 12/16, 90-237 Łódź, Poland

3 Department of Molecular Biology and Translational Research, Institute of Rural Health, Jaczewskiego 2, 20-090 Lublin, Poland

4 Department of Medical Biology and Translational Research, Faculty of Medicine, University of Information Technology and Management, Sucharskiego 2, 35-225 Rzeszów, Poland expression profile of LUHMES cells is presented for the first time and widely discussed.

Keywords Parkinson's disease - Gene expression · 6-hydroxydopamine $\cdot$ LUHMES cells · PGAM5

\section{Introduction}

Parkinson's disease (PD) is the second most common neurodegenerative disorder affecting mainly elderly people. Till know, the detailed mechanism responsible for its development remains unknown. The presently used therapies are mainly symptomatic and alleviate only a part of the symptoms that dramatically deteriorate the quality of life of the patients. Taking to account the aging of the population of many developed countries and enormous socio-economical burden caused by PD, research regarding the disease are considered as one of the main healthcare priorities for the society (Dexter and Jenner 2013).

This study was aimed at evaluating the effects of phosphoglyceromutase 5 (PGAM5) overexpression in the cellular model of Parkinson's disease, 6-hydroxydopamine (6OHDA)-treated differentiated human embryonic mesencephalic cells of the Lund Human Mesencephalic (LUHMES) cell line. PGAM5 is a recently discovered mitochondrial protein that may be strongly implicated in the molecular processes responsible for the development of PD. It was discovered as a regulator of the NRF2/KEAP1 pathway which is the main pathway responsible for triggering transcription of a battery of antioxidant and prosurvival genes in response to oxidative and electrophile stressors (Lo and Hannink 2008; Venugopal and Jaiswal 1996). The NRF2/KEAP1 pathway is responsible for the alleviation of the effects of PD model toxins, both in vitro 
and in vivo (Chen et al. 2009; Cuadrado et al. 2009; Lee et al. 2003; Shin 2014). Moreover, the neuroprotective effects of the so-called "chemopreventive natural dietary compounds", such as curcumin, resveratrol, or sulforaphan, are also mediated by the NRF2/KEAP1 signaling pathway. PGAM5 was found to bind the antiapoptic protein Bcl-xL and regulate its KEAP1-dependent ubiquitination and subsequent degradation (Lo and Hannink 2006). On the other hand, PGAM5 itself is a KEAP1 target and tethers the whole NRF2-KEAP1 complex to the mitochondrion. Silencing the PGAM5 increased the NRF2-dependent transcription in HeLa cells (Lo and Hannink 2008). It is plausible to assume that PGAM5 might be responsible for the fine tuning of the NRF2/KEAP1-dependent apoptic or survival response during oxidative stress (Stepkowski and Kruszewski 2011). It was recently shown that PGAM5 indirectly mediated Bcl-xL degradation in irradiated prostate cancer cells and this process was responsible for their radiosensitization by parthenolide. Interestingly, in normal cells the same compound protected against cell death by activating NRF2-dependent transcription (Xu et al. 2013).

PGAM5 is also responsible for dephosphorylating and activating ASK1, a higher order MAP kinase responsible for induction of neuronal apoptosis via p38- JNK axis in 6-OHDA and 1-methyl-4-phenyl-1,2,3,6-tetrahydropyridine (MPTP) models of PD (Ouyang and Shen 2006; Takeda et al. 2009).

Finally, the importance of PGAM5 in mechanisms involved in the development of PD was directly shown by $\mathrm{Lu}$ et al. (2014), who found out that knockout of PGAM5 in mouse cause a Parkinson's like movement disorder. This pathogenic state was caused by the impairment of PINK1mediated mitophagy. The importance of PGAM5 in PINK1/PARKIN-mediated mitophagy is also well supported by the previous in vitro studies (Sekine et al. 2012).

In this work, we used one of the most advanced in vitro models of PD, namely differentiated LUHMES cells treated with 6-OHDA (Lotharius et al. 2005; Schildknecht et al. 2009). Unlike commonly used neuroblastoma cell lines: SH-SY5Y or BE2-M17, LUHMES cells differentiation is imprinted intrinsically rather than induced by external factors, e.g., retinoic acid. The LUHMES cells are kept in undifferentiated, proliferating stage by the expression of v-myc oncogene under control of Tet element promoter that is silenced in the presence of tetracyclin. Addition of the antibiotic and ablation of the fibroblast growth factor from the medium lead to differentiation of the cells into post-mitotic neurons phenotypically similar to mature human dopaminergic neurons. 6-OHDA is a prooxidative neurotoxin commonly used to model PD in rodents. The intrastriatal administration of 6-OHDA in rodents creates pathological events similar to human PD: formation of aggregated alpha synuclein bodies, proteasome inhibition, increased ubiquitination, nitration and oxidation of proteins, gluthathione depletion, and caspase 3 cleavage (Blesa et al. 2012). 6-OHDA-mediated effects are not dependent on a direct inhibition of mitochondrial electron transport chain, but rather by the early oxidative stress events that can be alleviated by the action of NRF2/KEAP1 pathway, and therefore possibly modified by alternating levels of PGAM5 (Cao et al. 2005). To find out whether increased cellular abundance of PGAM5 protein change the effects of 6-OHDA exposure, we analyzed the expression of 86 PD-related genes in lentiviral transduced LUHMES cells.

\section{Materials and Methods}

\section{Cell Culture}

LUHMES cells were grown in monolyer on Nunclon $\Delta^{\mathrm{TM}}$ cell culture flasks coated with poly-L-ornithine $(50 \mu \mathrm{g} / \mathrm{mL})$ and human plasma fibronectin $(1 \mu \mathrm{g} / \mathrm{mL})$ (Sigma-Aldrich). Filter sterilized poly-L-ornithine was mixed with fibronectin, poured directly to the culture flasks $(1 \mathrm{~mL}$ per $10 \mathrm{~cm}^{2}$ ) and left overnight at $37{ }^{\circ} \mathrm{C}$. The coating mixture was then aspirated and the flasks were dried in the laminar hood. Freshly coated flasks were used in each experiment.

Undifferentiated, proliferating cells were grown in Advanced DMEM/F-12 medium (Life Technologies) supplemented with N-1 supplement (Sigma-Aldrich, N6530), basic fibroblast growth factor (bFGF) (Life Technologies) and $2 \mathrm{mM}$ L-glutamine. Differentiation was conducted according to the previously established two-step protocol (Scholz et al. 2011). Briefly, when cells reached $70 \%$ confluency medium was changed to a differentiation medium containing $1 \mu \mathrm{g} / \mathrm{mL}$ tetracycline instead of bFGF. On the next day (attributed as Day 2 of differentiation) cells were trypsinized and seeded to the new flasks to create a monolayer of separated differentiated cells without visible clumps of unequally differentiated cells. Cells were differentiated for 7 days before performing the final experiment.

\section{Lentiviral Transduction}

Lentiviral plasmids were designed in the Centre for Radiobiology and Biological Dosimetry to allow simultaneous expression of mitochondrially targeted DsRed2 and long (289 amino acids) isoform of PGAM5 (CCDS53845.1) (further referred as PGAM5_L). Two lentiviral constructs built on the pLV.Des2d.P_mitoDsRed2 backbone were used in this study: PGAM5_L cDNA plasmid and control mock plasmid containing MCS and 3* FLAG sequence instead of PGAM5_L sequence. 
Both plasmids contained mtDsRed 2 under the control of P1 promoter. PGAM5_L transcription was driven by the EF1 alpha promoter. The detailed maps of the viral vectors used in this study are provided as supplementary material (Supplementary Fig. 1). Lentiviruses packaging was outsourced (CYAGEN biosciences). On the first day of LUHMES cells differentiation lentiviral particles were added to the differentiation medium supplemented with $4 \mu \mathrm{g} / \mathrm{mL}$ Polybrene $\left(10^{6}\right.$ viral particles per $\left.1 \mathrm{~mL}\right)$. After overnight transduction medium was removed and the cells were subcultured into $21 \mathrm{~cm}^{2}$ flasks for further differentiation for 6 days.

\section{6-Hydroxydopamine Treatment}

6-Hydroxydopamine hydrochloride (Sigma-Aldrich H4381) was dissolved in $1 \%$ ascorbic acid before every experiment and protected from light. Fresh 6-OHDA solution was added directly to culture medium for $6 \mathrm{~h}$, to achieve the final concentration $100 \mu \mathrm{M}$. Control cells were treated with the appropriate vehicle buffer.

\section{Microscopy Imaging}

All pictures were taken with NIKON A1 fluorescence microscope equipped with NIS ELEMENTS software. NIKON $20 \times$ and $40 \times$ plan fluor objectives were used. Live cell imaging was done with the use of Hoffman modulation contrast, which is compatible with plastic cell culture dishes. Nuclei were stained with Hoechst 33342 in concentration of $2 \mu \mathrm{g} / \mathrm{mL}$. To visualize neurite net, we used a lipofilic dye, Dil Stain (1, $1^{\prime}$-dioctadecyl-3,3, $3^{\prime}, 3^{\prime}$ tetramethylindocarbocyanine perchlorate, Molecular Probes).

\section{RNA Isolation, Reverse Transcription, and Real- Time PCR}

Total RNA was extracted from the cell pellets using ReliaPrep $^{\mathrm{TM}}$ mini prep system (Promega), according to the manufacturer's protocol. RNA concentration and purity were assessed photometrically using A260/A280 ratio. RNA integrity was tested by agarose gel electrophoresis. $700 \mathrm{ng}$ of the total RNA were converted to cDNA using

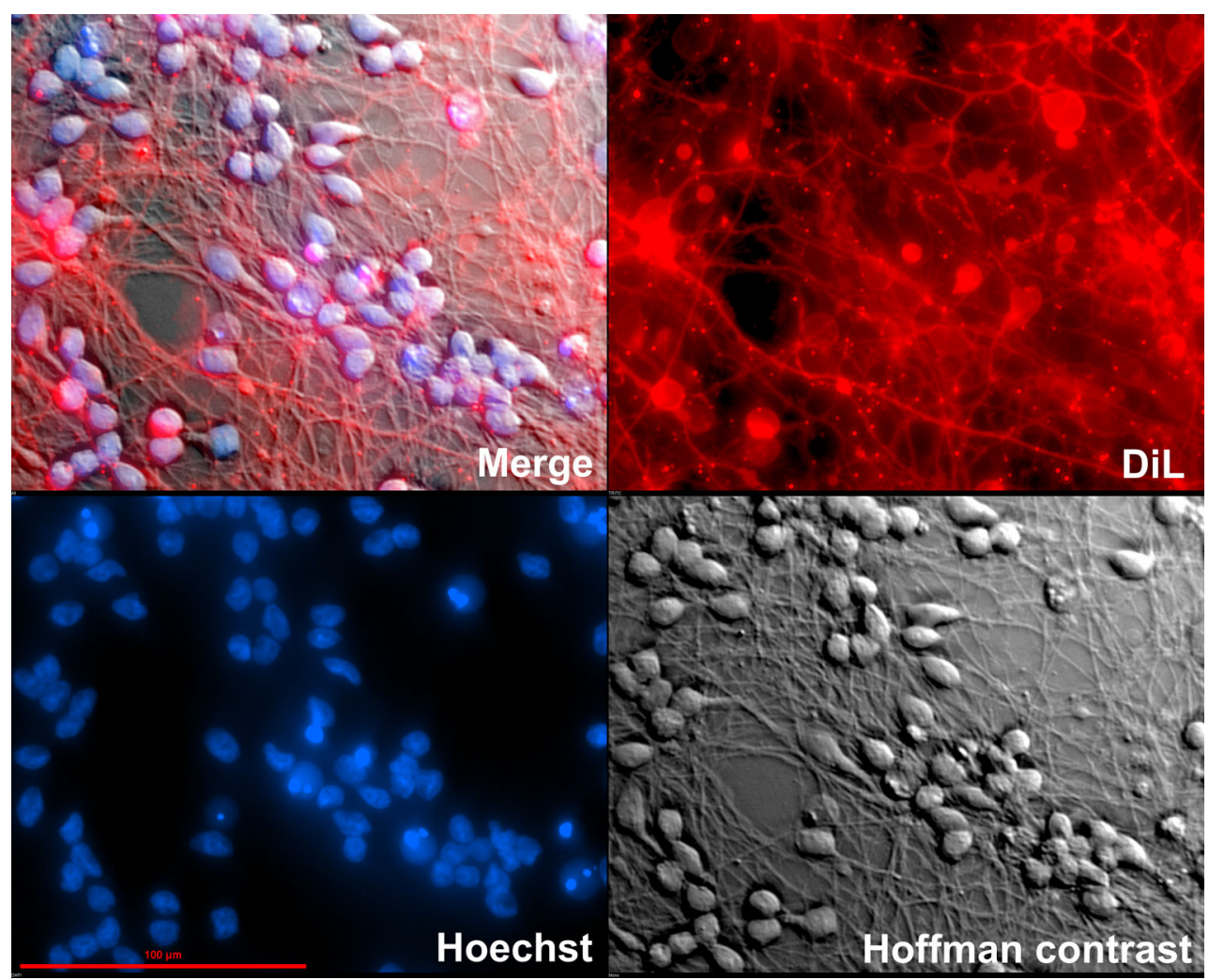

Fig. 1 The morphology of differentiated LUHMES cells. Lipofilic dye DiL was used to visualize the neurites. Nuclei were stained with Hoechst dye and cell bodies were observed in bright field with Hoffman modulation contrast. All pictures were taken at $\times 40$ magnitude 
RT $^{2}$ First Strand Kit (SABiosciences). The cDNA was used for the expression profiling by the Human Parkinson "s RT ${ }^{2}$ Profiler PCR Array (SABiosciences, cat. no. PAHS-124 Z), according to the manufacturer's instructions. This array allows for measurement of the expression of 84-genes, directly or potentially related to the PD (involved in Parkin pathway, cell adhesion, ubiquitin pathway, apoptosis, and inflammation, mitochondria metabolism, neuronal signaling, cytoskeletal organization, and genes related to the ion transport). For detailed list of genes see the manufacturer webpage, http://www.sabiosciences.com. cDNA amount corresponding to $6.35 \mathrm{ng}$ of the total RNA was used for a single well reaction, to achieve an average $C_{t}$ of 23 . Relative gene expression was calculated using the $\Delta \Delta \mathrm{C}_{\mathrm{t}}$ method with HPRT1, GAPDH, and B2M genes, as the reference controls. Calculations were done using $\mathrm{RT}^{2}$ Profiler PCR Array Data Analysis Template provided by SABiosciences. Statistical differences were examined by Student's t test with $p<0.02$ considered to be statistically significant. Overexpression of PGAM5_L mRNA was additionally tested by Real-Time PCR using a Taqman ${ }^{\circledR}$ probe specific for all PGAM5 isoforms according to a manufacturer protocol (Life Technologies).

\section{Western Blot Analysis}

The protein concentration was determined using the Bradford method. $30 \mu \mathrm{g}$ of cell lysates (1\% Nonidet buffer) were boiled for $10 \mathrm{~min}$ at $60{ }^{\circ} \mathrm{C}$ in Laemmli sample buffer. After that samples were loaded on $12 \%$ SDSPAGE polyacrylamide gel and separated. After protein transfer to PVDF membranes (BioRad), membranes were blocked for $1 \mathrm{~h}$ with $5 \%$ milk at $4{ }^{\circ} \mathrm{C}$ and incubated with primary antibodies diluted in blocking solution overnight $\left(4{ }^{\circ} \mathrm{C}\right.$ ). Primary antibodies (Abcam 126534) were then detected with HRP-conjugated secondary antibodies and chemiluminescence was triggered by Western Bright ECL reagent (Advansta) as substrate, and recorded on CLXPosure films (Pierce). Blots and films were scanned. Molecular weight of protein bands was estimated in comparison to BenchMark Prestained protein ladder (Invitrogen).

\section{Results}

\section{Differentiation and Morphology of Mature, Post- mitotic Neurons is not Affected by PGAM5_L Overexpression}

LUHMES cells were transduced at the first day of differentiation with efficiency around $90 \%$, as estimated by DsRed2 fluorescence. Overexpression of PGAM5 long isoform was confirmed by Real-Time PCR and Western Blot. The PGAM5_L mRNA was 8 times more abundant in transduced LUHMES cells (Fig. 2b). Antibody against PGAM5_L protein detected two bands around $32 \mathrm{kDa}$, which were identified as PGAM5 long isoform and the product of its cleavage by PARL protease (Sekine et al. 2012; Wang et al. 2012). In PGAM5_L overexpressing cells the PARL-proteolytic form was more abundant than intact protein. Conversely, in mock-transduced cells the protein band attributed to intact protein was more intense than the band characteristic for proteolytic PGAM5 form. Furthermore, an additional band around 28-30 kDa was detected in lysates of PGAM5_L overexpressing cells suggesting the existence of an unknown smaller proteolytic form (Fig. 2a).

Daily live cell imaging revealed that neither PGAM5_L overexpression nor introduction of mtDsRed2 had any effect on LUHMES cells differentiation or cell morphology. Both, mtDsRed2 transduced (mock transduction) and PGAM5_L overexpressing cells (mtDsRed2 + PGAM5_L) uniformly changed their phenotype to typical neuronal shape (Figs. 1, 3). We also observed no differences when we compared the pattern of wild type cells differentiation with transductants differentiation (data not shown). Neurite outgrowth started to be visible at the third day of differentiation and after 5 day cells created a highly interconnected and multi-branched "neuronal net" as described by a previously established protocol (Scholz et al. 2011).

\section{6-OHDA Treatment, But not the PGAM5_L Overexpression, cause Profound Changes in the Expression of PD-Related Genes}

We assayed the expression of 84 genes directly or potentially involved in PD etiology. All the genes included in the analysis are connected with PD development or their expression changed in various animal models of PD.

The analysis revealed no statistically significant differences in PD-related gene expression between the mock transduced and PGAM5_L overexpressing cells. Consequently, only small, statistically not significant changes in gene expression were observed between mock transduced and PGAM5_L overexpressing cells treated with 6-OHDA. Nevertheless, the treatment of LUHMES cells with 6-OHDA significantly affected PD-related genes expression. As PGAM5 overexpression did not affect 6-OHDAinduced gene expression, to calculate 6-OHDA-induced gene expression changes the results of both groups (PGAM5 and mock transduced) were pooled to further strengthen the statistical significance of fold regulation levels.

Among 84 assayed genes, the expression of 44 changed more than $20 \%(p \leq 0.02), 11$ were up-regulated and 33 
Fig. 2 PGAM5 expression in lentivirally transduced LUHMES cells. a The abundance of PGAM5_L protein was analyzed by Western Blot. b The overexpression of PGAM5_L mRNA was quantified in RealTime PCR. Error bars represent SD of fold change calculated from three independent experiments

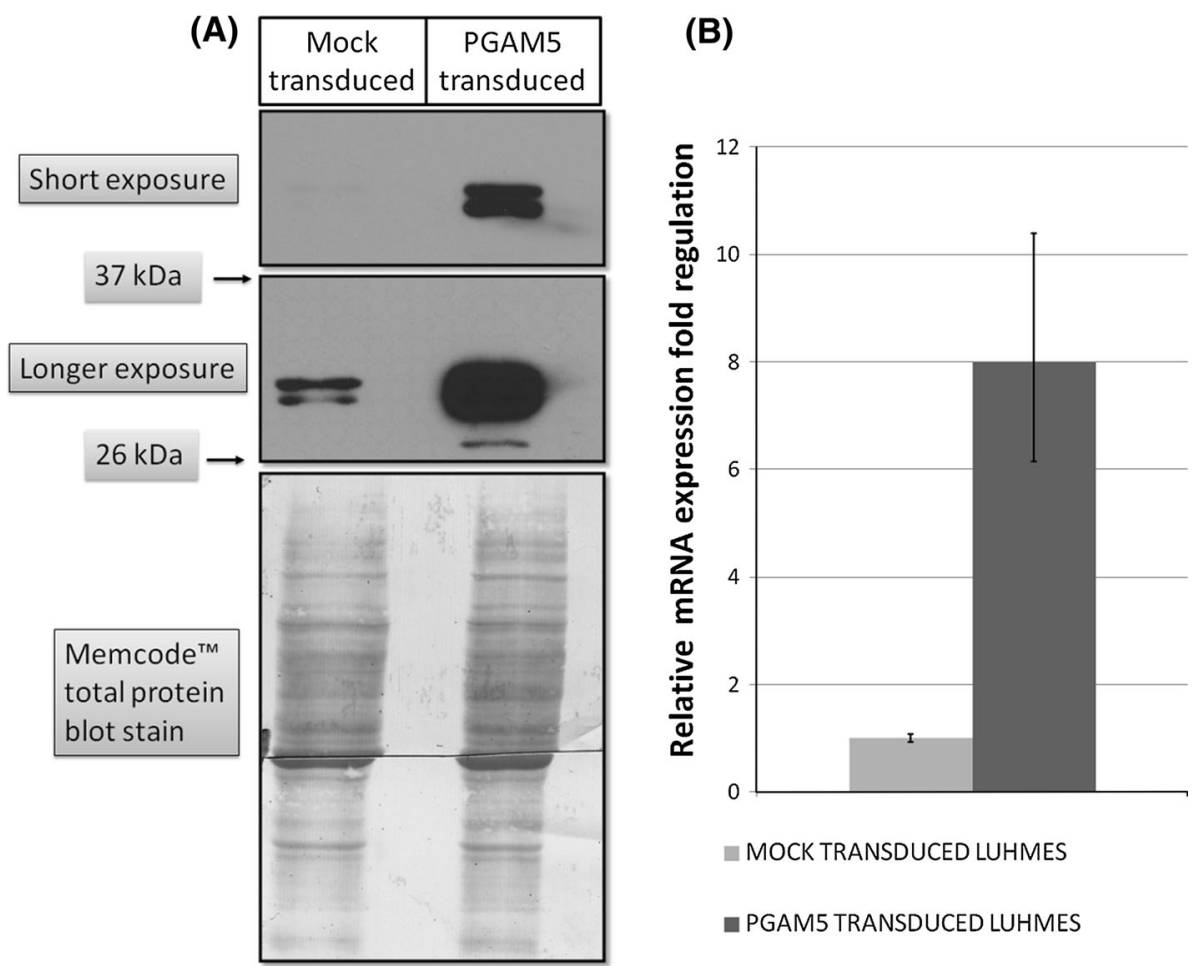

were down-regulated. Among those, the expression of 20 genes changed more than $200 \%(p \leq 0.020)$ (Table 1$)$. Considering functional gene groups assayed, we did not observe the gene expression changes in genes related to inflammation. The most abundant gene expression changes were observed for genes related to: mitochondria, ion transport, cell adhesion, and interconnection/vesicle signaling (Table 2).

\section{Discussion}

It was previously shown that PGAM5 regulates mitophagy in response to mitochondria depolarizing agent CCCP or hypoxia, by two distinct mechanisms (Sekine et al. 2012; Wu et al. 2014). Very recently, Pgam5 knockout mice were analyzed and PGAM5 role in mitophagy induction was established in an animal model. Mice lacking Pgam5 gene were characterized by a PD like movement disorder, which is thought to be mediated by a dopaminergic neurons degeneration due to an inefficient mitophagy (Lu et al. 2014). Thus, it was of interest to elucidate whether PGAM5 overexpression would affect the action of the model PDinducing toxin, 6-OHDA.

While the Pgam5 deficiency resulted in the induction of PD resembling disorder in knock out mice, over expression of the protein in differentiated neurons (LUHMES cells) did not change the gene expression of any of the tested 84
PD-related genes, neither in vehicle-treated control nor in $100 \mu \mathrm{M}$ 6-OHDA-treated cells. It is plausible that PGAM5 post translation modifications are more important for mediating its biological role than its abundance or upregulation does not have as pronounced biological effects as its knockdown.

mtDsRed2 was introduced into lentiviral plasmids to act as a transduction control and to allow visualization of mitochondria dynamics. Judging from the mtDsRed2 fluorescence, its expression was relatively low, but high enough to act as a transduction efficiency control. We hypothesize that this could have been caused by P1 promoter silencing and/or promoter or protein coding sequence mutation. Nevertheless, low mtDsRed2 expression was not consistent with change in the expression of PGAM5, which was driven by the different promoter. Due to limited resources and fact that weak mtDsRed2 expression is even beneficial because that strong mtDsRed2 expression might have interfered with biological effects of PGAM5 overexpression, we have not further studied this problem and used mtDsRed 2 only as a transduction efficiency control.

PINK1 and PARK2 (coding PARKIN E3 ubiquitin ligase) are one of the currently known 12 genes, whose monogenic mutations are found in genomes of patients suffering from early or juvenile onset PD (Bonifati 2014). Those two genes work in a common signaling pathway responsible for triggering selective autophagy of 


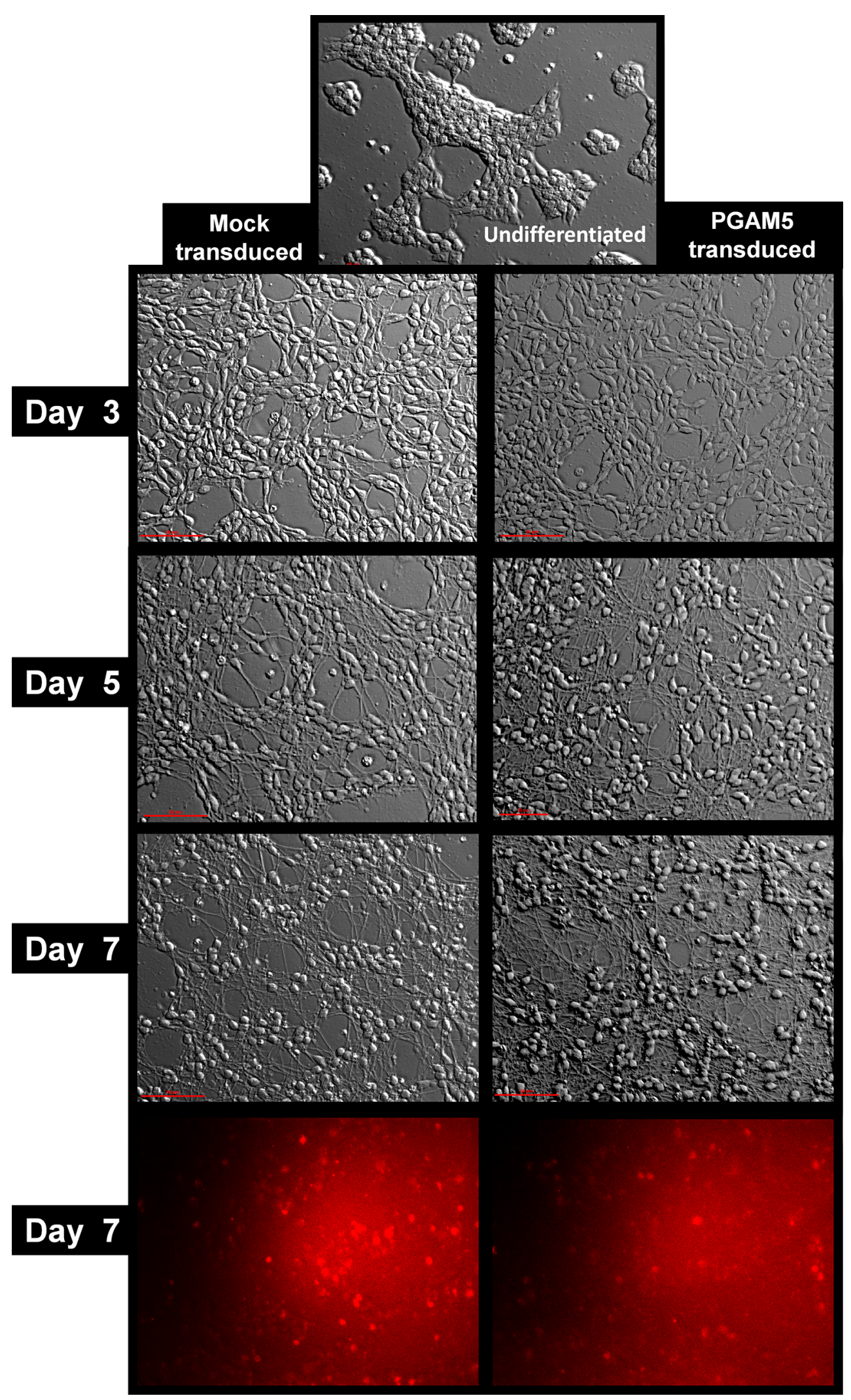

Fig. 3 LUHMES cells morphology during differentiation is not influenced by PGAM5 transduction. Pictures of LUHMES cells, mock or PGAM5_L transduced, were taken in $\times 20$ magnitude in
Hoffman modulation contrast at third, fifth and seventh day of differentiation. Same cells were analyzed for red fluorescence of DsRed2 (the marker of transduction) 
Table 1 PD-related genes expression fold change in the LUHMES cells treated with $100 \mu \mathrm{M}$ 6-OHDA

\begin{tabular}{|c|c|c|c|c|}
\hline Gene name & $\begin{array}{l}\text { Gene } \\
\text { symbol }\end{array}$ & Aliases & $\begin{array}{l}\text { Student's } \\
t \text { test } \\
p \text { value }\end{array}$ & $\begin{array}{l}\text { Fold } \\
\text { regulation }\end{array}$ \\
\hline Serine/arginine-rich splicing factor 7 & SRSF7 & 9G8, AAG3, SFRS7 & $p<10^{-9}$ & 2,272407525 \\
\hline Adenomatous polyposis coli & $A P C$ & BTPS2, DP2, DP2.5, DP3, GS, PPP1R46 & $p<10^{-8}$ & $-3,515342822$ \\
\hline Phosphatase and tensin homolog & PTEN & $\begin{array}{l}\text { 10q23del, BZS, CWS1, DEC, GLM2, MHAM, } \\
\text { MMAC1, PTEN1, TEP1 }\end{array}$ & $p<10^{-8}$ & $-2,324764994$ \\
\hline $\mathrm{N}$-ethylmaleimide-sensitive factor & $N S F$ & $S K D 2$ & $p<10^{-7}$ & $-2,453703041$ \\
\hline $\begin{array}{l}\text { Cell division cycle } 27 \text { homolog ( } \mathrm{S} . \\
\text { cerevisiae) }\end{array}$ & $C D C 27$ & $\begin{array}{l}\text { ANAPC3, APC3, CDC27Hs, DOS1430E, } \\
\text { D17S978E, HNUC, NUC2 }\end{array}$ & $p<10^{-7}$ & $-1,992708428$ \\
\hline $\begin{array}{l}\text { Cell division cycle } 42 \text { (GTP binding } \\
\text { protein, } 25 \mathrm{kDa})\end{array}$ & $C D C 42$ & CDC42Hs, G25 K & $p<10^{-7}$ & $-1,534069252$ \\
\hline $\begin{array}{l}\text { Ubiquitin-like modifier activating enzyme } \\
1\end{array}$ & $U B A 1$ & $\begin{array}{l}\text { A1S9, A1S9T, A1ST, AMCX1, GXP1, POC } 20, \\
\text { SMAX2, UBA1A, UBE1, UBE1X }\end{array}$ & $p<10^{-7}$ & $-1,595294085$ \\
\hline Cullin 2 & CUL2 & - & $p<10^{-6}$ & $-2,3082953$ \\
\hline Optic atrophy 1 (autosomal dominant) & OPA1 & $M G M 1, N P G, N T G$, large $G$ & $p<10^{-6}$ & $-1,780188065$ \\
\hline Actin, beta & $A C T B$ & $B R W S 1, P S 1 T P 5 B P 1$ & $p<10^{-6}$ & $-1,562033576$ \\
\hline $\begin{array}{l}\text { Vesicle-associated membrane protein } 1 \\
\text { (synaptobrevin 1) }\end{array}$ & $V A M P 1$ & $S Y B 1, V A M P-1$ & $p<10^{-6}$ & 5,010440698 \\
\hline PTEN-induced putative kinase 1 & PINK1 & $B R P K$, PARK6 & $p<10^{-6}$ & $-1,507431572$ \\
\hline Amyloid beta (A4) precursor protein & $A P P$ & $\begin{array}{l}\text { AAA, ABETA, ABPP, AD1, APPI, CTFgamma, } \\
\text { CVAP, PN-II, PN2 }\end{array}$ & $p<10^{-6}$ & $-1,745533857$ \\
\hline Reticulon 1 & RTN1 & $N S P$ & $p<10^{-6}$ & $-1,502605119$ \\
\hline Egl nine homolog 1 (C. elegans) & EGLN1 & $\begin{array}{l}\text { Clorf12, ECYT3, HIF-PH2, HIFPH2, HPH-2, } \\
\text { HPH2, PHD2, SM20, ZMYND6 }\end{array}$ & $p<10^{-6}$ & 1,525649248 \\
\hline Heat shock $70 \mathrm{kDa}$ protein 4 & HSPA4 & APG-2, HS24, P52, HSPH2, RY, hsp70, hsp70RY & $p<10^{-5}$ & $-2,832602738$ \\
\hline $\begin{array}{l}\text { G protein-coupled receptor } 37 \text { (endothelin } \\
\text { receptor type B-like) }\end{array}$ & GPR37 & $E D N R B L, P A E L R, h E T(B) R-L P$ & $p<10^{-5}$ & $-1,986643383$ \\
\hline $\mathrm{Ca}++$-dependent secretion activator & $C A D P S$ & CADPS1, CAPS, CAPS1 & $p<10^{-5}$ & $-2,981895566$ \\
\hline $\begin{array}{l}\text { Caspase } 3 \text {, apoptosis-related cysteine } \\
\text { peptidase }\end{array}$ & CASP3 & CPP32, СРP32B, SCA-1 & $p<10^{-5}$ & $-2,03831021$ \\
\hline Voltage-dependent anion channel 3 & VDAC3 & $H D-V D A C 3, V D A C-3$ & $p<10^{-5}$ & $-1,494780659$ \\
\hline $\begin{array}{l}\text { Parkinson protein 2, E3 ubiquitin protein } \\
\text { ligase (parkin) }\end{array}$ & PARK2 & $A R-J P, L P R S 2, P D J, P R K N$ & $p<10^{-4}$ & $-2,369409925$ \\
\hline $\mathrm{S}$-phase kinase-associated protein 1 & SKP1 & EMC19, OCP-II, OCP2, SKP1A, TCEB1L, p19A & $p<10^{-4}$ & $-1,4349779$ \\
\hline Synaptotagmin I & SYT1 & $P 65, S V P 65, S Y T$ & $p<10^{-4}$ & $-2,755530058$ \\
\hline Parkinson protein 7 & PARK7 & $D J-1, D J 1, H E L-S-67 p$ & $p<10^{-4}$ & $-1,575583282$ \\
\hline Ataxin 3 & ATXN3 & $\begin{array}{l}\text { AT3, ATX3, JOS, MJD, MJD1, RP11-529H20.5, } \\
\quad \text { SCA3 }\end{array}$ & $p<10^{-4}$ & $-1,782955859$ \\
\hline Glucan (1,4-alpha-), branching enzyme 1 & $G B E 1$ & $A P B D, G B E, G S D 4$ & $p<10^{-3}$ & $-1,685484474$ \\
\hline F-box protein 9 & FBXO9 & FBX9, NY-REN-57, VCIA1, dJ341E18.2 & $p<10^{-3}$ & $-1,530293431$ \\
\hline Cadherin 8 , type 2 & $\mathrm{CDH} 8$ & Nbla04261 & $p<10^{-3}$ & 2,737917368 \\
\hline $\begin{array}{l}\text { Synuclein, alpha (non A4 component of } \\
\text { amyloid precursor) }\end{array}$ & $S N C A$ & NACP, PARK1, PARK4, PD1 & $p<10^{-3}$ & $-2,93448938$ \\
\hline Synaptic vesicle glycoprotein $2 \mathrm{~B}$ & $S V 2 B$ & $H s T 19680$ & $p<10^{-3}$ & $-2,272650385$ \\
\hline Dopamine receptor D2 & $D R D 2$ & $D 2 D R, D 2 R$ & $p<10^{-3}$ & 1,520682705 \\
\hline Delta-like 1 homolog (Drosophila) & $D L K 1$ & $\begin{array}{l}\text { DLK, DLK-1, Delta1, FA1, PREF1, Pref-1, } \\
\quad \text { ZOG, } p G 2\end{array}$ & $p<10^{-3}$ & $-2,493362532$ \\
\hline Regulator of G-protein signaling 4 & $R G S 4$ & $R G P 4, S C Z D 9$ & $p<10^{-3}$ & $-1,823980398$ \\
\hline S100 calcium binding protein $B$ & $S 100 B$ & NEF, S100, S100-B, S100beta & $p<10^{-3}$ & 5,504391369 \\
\hline
\end{tabular}


Table 1 continued

\begin{tabular}{|c|c|c|c|c|}
\hline Gene name & $\begin{array}{l}\text { Gene } \\
\text { symbol }\end{array}$ & Aliases & $\begin{array}{l}\text { Student's } \\
t \text { test } \\
p \text { value }\end{array}$ & $\begin{array}{l}\text { Fold } \\
\text { regulation }\end{array}$ \\
\hline CXXC finger protein 1 & $C X X C 1$ & $\begin{array}{l}\text { 2410002I16Rik, 5830420C16Rik, CFP1, CGBP, } \\
\text { HsT2645, PCCX1, PHF18, SPP1, ZCGPC1, } \\
\text { hCGBP }\end{array}$ & $p<10^{-3}$ & 1,54484259 \\
\hline $\begin{array}{l}\text { Caspase } 8 \text {, apoptosis-related cysteine } \\
\text { peptidase }\end{array}$ & CASP8 & ALPS2B, CAP4, Casp-8, FLICE, MACH, MCH5 & $p<10^{-2}$ & 3,087237999 \\
\hline $\begin{array}{l}\text { Aldehyde dehydrogenase } 1 \text { family, } \\
\text { member A1 }\end{array}$ & $A L D H 1 A 1$ & $\begin{array}{l}A L D C, A L D H-E 1, A L D H 1, A L D H 11, H E L-S- \\
53 e, H E L 12, P U M B 1, R A L D H 1\end{array}$ & $p<10^{-2}$ & 2,151296669 \\
\hline $\begin{array}{l}\text { Potassium inwardly-rectifying channel, } \\
\text { subfamily J, member } 6\end{array}$ & KCNJ6 & $\begin{array}{l}\text { BIR1, GIRK-2, GIRK2, KATP-2, KATP2, } \\
\text { KCNJ7, KIR3.2, hiGIRK2 }\end{array}$ & $p<10^{-2}$ & $-1,526711915$ \\
\hline Trophoblast glycoprotein & $T P B G$ & $5 T 4,5 T 4 A G, M 6 P 1$ & $p<10^{-2}$ & 2,045570763 \\
\hline $\begin{array}{l}\text { Dopa decarboxylase (aromatic L-amino } \\
\text { acid decarboxylase) }\end{array}$ & $D D C$ & $A A D C$ & $p<10^{-2}$ & $-2,037636174$ \\
\hline $\begin{array}{l}\text { Caspase 1, apoptosis-related cysteine } \\
\text { peptidase (interleukin 1, beta, } \\
\text { convertase) }\end{array}$ & CASP1 & $I C E, I L 1 B C, P 45$ & $p<0,02$ & 1,993516068 \\
\hline Neurofilament, light polypeptide & $N E F L$ & $C M T 1 F, C M T 2 E, N F-L, N F 68, N F L$ & $p<0,02$ & $-1,225922474$ \\
\hline $\begin{array}{l}\text { Transcription factor 7-like } 2 \text { ( } \mathrm{T} \text { cell } \\
\text { specific, HMG-box) }\end{array}$ & $T C F 7 L 2$ & $T C F-4, T C F 4$ & $p<0,02$ & $-1,462013976$ \\
\hline $\begin{array}{l}\text { Solute carrier family } 18 \text { (vesicular } \\
\text { monoamine), member } 2\end{array}$ & SLC18A2 & SVAT, SVMT, VAT2, VMAT2 & $p<0,02$ & $-1,390565564$ \\
\hline
\end{tabular}

Over expressed gene names are highlighted in italic font. Statistical differences were examined by Student's t test with $p<0.02$ considered to be statistically significant. Only statistically significant gene expression changes higher than $20 \%$ are shown. The $p$ values and fold regulation levels were calculated from six experiments

mitochondria and regulating mitochondria transport (Pickrell and Youle 2015; Scarffe et al. 2014). The treatment with $100 \mu \mathrm{M}$ 6-OHDA caused down regulation of two cytoprotective genes and members of the Parkin complex: HPS70 and PARK7 (coding DJ-1 protein). The HPS70 and DJ-1 proteins bind each other to regulate the cellular defense mechanism linked to oxidative insults (Moore et al. 2005). PARK7 is one of the five known genes whose mutations have been linked to familial forms of PD. DJ-1 is generally considered being cytoprotective, as it is up-regulated during oxidative stress and it is able to rescue cells from apoptosis in response to parkinsonian toxins (Bonifati et al. 2003; Inden et al. 2006; Yokota et al. 2003). In SH-SY5Y neuroblastoma cells DJ-1 is up-regulated in response to 6-OHDA (Lev et al. 2008). Interestingly, in LUHMES cells, we have observed a half-fold decrease in DJ-1 expression $\left(p<10^{-4}\right)$ and almost 3-fold decrease in HSPA4 $\left(p<10^{-5}\right)$. This may indicate that LUHMES cells are more sensitive to oxidative insults. Moreover, PINK1 and alpha synuclein, other genes mutated in mendelian forms of PD, were also down-regulated in LUHMES cells in response to 6-OHDA. It seems that the observed downregulation of cytoprotective genes related to parkin complex is accompanied by the pro-apoptic rather than prosurvival effect. Indeed, we also observed the three-fold upregulation of the initiator caspase 8 .
The most profound changes in gene expression were observed for synaptobrevin 1 coded by VAMP1 gene (5fold up-regulation, $p<10^{-6}$ ) and adenomatous polyposis coli gene $\left(3.5\right.$-fold down-regulation $\left.p<10^{-8}\right)$.

The synaptobrevin 1 is a member of the family of vesicle-associated membrane proteins (VAMPs) that are a part of the SNARE complex involved in vesicle fusion during synaptic signaling and autophagy (Shih et al. 2005). Apart from VAMP1 up-regulation, we have observed the 6-OHDA-induced decrease in expression of three other genes, whose protein products are directly related to synaptic vesicle signaling: synaptotagmin (SYT1, -2.7-fold), synaptic vesicle glycoprotein $(S V 2 B,-2.2$-fold) and calcium-dependent activator protein for secretion (CADPS, -2.9 -fold). All of those proteins are implicated in the $\mathrm{Ca}^{2+}$-dependent exocytosis. Synaptobrevins are known to be targeted and degraded by tetanospasmin and botulinum-neurotoxins produced by anaerobic pathogens from Clostridium sp. (Binz et al. 2010). The serotypes of those neurotoxins are highly specific toward particular orthologues of VAMP proteins present in different regions of the organism (Yamamoto et al. 2012). Brain orthologues VAMP1 and VAMP2 are present in different regions of the rat brain (Ferecskó et al. 2015; Raptis et al. 2005). Mendieta et al. (2012) shown that C- terminal part of tetanus toxin, when administered by muscle injection 
Table 2 The functional groups of PD-related genes and their expression regulation in response to 6-OHDA

\begin{tabular}{|c|c|}
\hline $\begin{array}{l}\text { Functional gene } \\
\text { group }\end{array}$ & Genes belonging to the group and their expression regulation in response to 6-OHDA \\
\hline Parkin complex & HSPA4 (HSP70), PARK7, STUB1 \\
\hline Parkin Substrate & ATXN2, ATXN3, GPR37, SYT11 \\
\hline Cell adhesion & APC, APP, CDH8, FN1, NFASC, NRXN3, PTEN, TPBG. \\
\hline Ubiquitination & $\frac{\mathrm{CDC} 27, \mathrm{CUL2}, \mathrm{FBXO} 9}{U C H L 1, U S P 34}, L R K 2, P A N 2$, PARK2, PINK1, SKP1, STUB1, UBB, UBA1, UBE2I, UBE2 K, UBE2L3, \\
\hline Inflammation & $F N 1, P R D X 2, Y W H A Z$ \\
\hline Apoptosis & 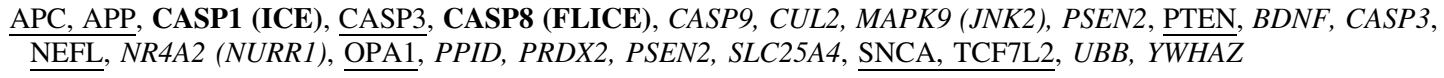 \\
\hline Mitochondria & $\begin{array}{l}\text { CASP3, CASP7, CASP8 (FLICE), HSPA4 (HSP70), LRRK2, NEFL, OPA1, PARK7, PINK1, PTEN, SLC25A4, SNCA, } \\
T H, U C H L 1, \text { VAMP1, VDAC3, YWHAZ }\end{array}$ \\
\hline Synaptic Vesicles & LRRK2, SEPT5, SV2B, SYNGR3, $\underline{\mathrm{SYT} 1}, \mathrm{SYT11}, \mathrm{TH}$ \\
\hline Signal Transduction & $\begin{array}{l}\text { Dopaminergic: NSG1, DDC, DRD2, HTR2A, NR4A2 (NURR1), PARK2, PARK7, PINK1, SEPT5, SLC6A3, SNCA, TH } \\
\text { GABAergic: DRD2, GABBR2 } \\
\text { MAP Kinase: } \underline{\mathrm{APC}}, F G F 13, M A P K 9 \text { (JNK2), PRDX2, } \underline{\mathrm{RGS} 4} \\
\text { Notch: } \underline{\mathrm{APP}}, \mathrm{PSEN} 2, \text { SPEN }\end{array}$ \\
\hline $\begin{array}{l}\text { Cytoskeletal } \\
\text { organization }\end{array}$ & APC, CDC42, MAPT, NEFL, PARK2. \\
\hline Ion transport & $\begin{array}{l}\text { ATP2B2, CADPS, CXXC1, DRD2, EGLN1, GBE1, GRIA3, HTR2A, KCNJ6, NSF, PSEN2, S100B, SRSF7, SLIT1, } \\
\text { SNCA, VDAC3 }\end{array}$ \\
\hline Transporters & ATP2B2, GRIA3, SLC18A2, SLC6A3, SLC25A4, SV2B, SYT1, SYT11, VDAC3 \\
\hline Others & ALDH1A1, BASP1, CHGB, DLK1, NCOA1, NTRK2, RTN1 \\
\hline
\end{tabular}

Up-regulated genes shown in bold. Down-regulated genes shown in undeline. Tested genes whose expression was not changed are highlighted in italic

protected rats from motor symptoms of Parkinson's disease induced by 6-OHDA. On the other hand, a case study was published describing severe parkinsonian symptoms observed after tetanus vaccination (Reijneveld et al. 1997). In view of our results, it is plausible that the neuroprotective effects of tetanospasmin C-terminal fragment could be at least partially mediated by its hydrolyzing activity against VAMPs, as we found VAMPl to be highly up-regulated in response to 6-OHDA in LUHMES cells. Fine tuning of VAMPs in different brain regions by the use of clostridium toxins or their derivates may be in future a promising therapeutical mechanism to treat neurological disorders.

Adenomatous polyposis coli gene $(A P C)$ is the second gene, which expression profoundly changed in 6-OHDAtreated LUHMES cells (3.5-fold down-regulation $p<10^{-8}$ ). This gene is mostly known for its tumor suppressing activities, and its mutation is associated with severe pre-malignant syndrome (Groden et al. 1991; Zhang et al. 2010). There is scare evidence of APC implications in Parkinson's disease, but it was found to be indispensible for the nicotine acetylcholine synapse assembly (Temburni et al. 2004). Furthermore, nicotine is believed to have neuroprotective role against PD, as various epidemiologic studies showed that smokers less frequently developed PD (Hernan et al. 2002; Tanaka et al. 2010).
The decrease in dopamine content in the central nervous system is the main cause of motor symptoms of PD. Our gene expression analysis was also focused on genes related to dopaminergic signaling. We found that 6-OHDA caused a two-fold decrease in the expression of DOPA decarboxylase, an enzyme which catalyzes a rate limiting step of dopamine synthesis. This decrease was accompanied by the $50 \%$ increase in the expression of dopamine receptor 2 . The increase in the expression of dopamine receptor 2 is probably a part of the compensation mechanism of dopaminergic neurons, as it has been shown that degeneration of striatal dopaminergic neurons is accompanied by the compensation mechanisms that allow maintaining dopamine concentrations at the unchanged levels (Golden et al. 2013; Zigmond et al. 1990).

The treatment with $100 \mu \mathrm{M}$ 6-OHDA led also to the 5.5fold increase in the expression of $S 100 B$ gene. $\mathrm{S} 100 \mathrm{~B}$ is a calcium binding peptide with plenty of known biological implications. S100 peptide is implicated in regulation of proliferation, differentiation, apoptosis, $\mathrm{Ca}^{2+}$ homeostasis, energy metabolism, inflammation, and migration/invasion through interactions with a variety of target proteins including enzymes, cytoskeletal subunits, receptors, transcription factors, and nucleic acids (Donato et al. 2013). $\mathrm{S} 100 \mathrm{~B}$ is a prototype biomarker for brain injuries including 
trauma and stroke. We found that in control cells the expression of S100B was very weak, while in 6-OHDAtreated cells it increased to the levels that could be reliably quantified by RT-PCR. S100B is expressed and released by astro and oligodendrocytes in response to glial activation or injury and was recently studied as a potential serum biomarker for traumatic brain injury, stroke, depression, and blood brain barrier injury (Blyth et al. 2009; Schroeter et al. 2013; Vos et al. 2004). S100B is also produced by glia cells in PD associated neuroinflammation (Niranjan 2014). The role of S100B up-regulation in 6-OHDAtreated LUHMES cells remains elusive, but may be involved in the processes of neurite outgrowth and/or cytoprotection as a part of the response to insults causing neurite degeneration, as S100B was attributed as a neurotropic factor (McAdory et al. 1998).

In conclusion for the first time, we presented a detailed analysis of PD-related gene expression in LUHMES cells treated with 6-OHDA and found out that the observed profile of expression was not influenced by the lentiviral overexpression of PGAM5 a protein recently implicated in various processes related to the development of PD. We believe that our results will be of help for researchers working on PGAM5 and Parkinson's Disease and that they will encourage them to use LUHMES cells that are currently emerging as a modern model for neurological disorders.

Acknowledgments The authors would like to thank Dr Kamil Brzóska for critically discussing RT-PCR results.

Funding This study was founded by IUVENTUS PLUS young researcher grant IP2011052071 from Polish Ministry of Science and Higher Education (T.M.S, A.G) and statutory grant for Institute of Nuclear Chemistry and Technology (I.W. and M.K.).

Conflict of interest The authors declare that they have no conflict of interest.

Open Access This article is distributed under the terms of the Creative Commons Attribution 4.0 International License (http:// creativecommons.org/licenses/by/4.0/), which permits unrestricted use, distribution, and reproduction in any medium, provided you give appropriate credit to the original author(s) and the source, provide a link to the Creative Commons license, and indicate if changes were made.

\section{References}

Binz T, Sikorra S, Mahrhold S (2010) Clostridial neurotoxins: mechanism of SNARE cleavage and outlook on potential substrate specificity reengineering. Toxins (Basel) 2:665-682

Blesa J, Phani S, Jackson-Lewis V, Przedborski S (2012) Classic and new animal models of Parkinson's disease. J Biomed Biotechnol 2012:845618

Blyth BJ, Farhavar A, Gee C, Hawthorn B, He H, Nayak A, Stocklein V, Bazarian JJ (2009) Validation of serum markers for bloodbrain barrier disruption in traumatic brain injury. J Neurotrauma 26:1497-1507
Bonifati V (2014) Genetics of Parkinson's disease-state of the art, 2013. Parkinsonism Relat Disord 20(Suppl 1):S23-S28

Bonifati V, Rizzu P, van Baren MJ, Schaap O, Breedveld GJ, Krieger E, Dekker MC, Squitieri F, Ibanez P, Joosse M, van Dongen JW, Vanacore N, van Swieten JC, Brice A, Meco G, van Duijn CM, Oostra BA, Heutink P (2003) Mutations in the DJ-1 gene associated with autosomal recessive early-onset parkinsonism. Science 299:256-259

Cao TT, Ma L, Kandpal G, Warren L, Hess JF, Seabrook GR (2005) Increased nuclear factor-erythroid 2 p45-related factor 2 activity protects $\mathrm{SH}-\mathrm{SY} 5 \mathrm{Y}$ cells against oxidative damage. J Neurochem 95:406-417

Chen PC, Vargas MR, Pani AK, Smeyne RJ, Johnson DA, Kan YW, Johnson JA (2009) Nrf2-mediated neuroprotection in the MPTP mouse model of Parkinson's disease: critical role for the astrocyte. Proc Natl Acad Sci USA 106:2933-2938

Cuadrado A, Moreno-Murciano P, Pedraza-Chaverri J (2009) The transcription factor Nrf2 as a new therapeutic target in Parkinson's disease. Expert Opin Ther Targets 13:319-329

Dexter DT, Jenner P (2013) Parkinson disease: from pathology to molecular disease mechanisms. Free Radic Biol Med 62:132-144

Donato R, Cannon BR, Sorci G, Riuzzi F, Hsu K, Weber DJ, Geczy CL (2013) Functions of S100 proteins. Curr Mol Med 13:24-57

Ferecskó AS, Jiruska P, Foss L, Powell AD, Chang WC, Sik A, Jefferys JG (2015) Structural and functional substrates of tetanus toxin in an animal model of temporal lobe epilepsy. Brain Struct Funct 220(2):1013-1029

Golden JP, Demaro JA III, Knoten A, Hoshi M, Pehek E, Johnson EM Jr, Gereau RW, Jain S (2013) Dopamine-dependent compensation maintains motor behavior in mice with developmental ablation of dopaminergic neurons. J Neurosci 33:17095-17107

Groden J, Thliveris A, Samowitz W, Carlson M, Gelbert L, Albertsen H, Joslyn G, Stevens J, Spirio L, Robertson M (1991) Identification and characterization of the familial adenomatous polyposis coli gene. Cell 66:589-600

Hernan MA, Takkouche B, Caamano-Isorna F, Gestal-Otero JJ (2002) A meta-analysis of coffee drinking, cigarette smoking, and the risk of Parkinson's disease. Ann Neurol 52:276-284

Inden M, Taira T, Kitamura Y, Yanagida T, Tsuchiya D, Takata K, Yanagisawa D, Nishimura K, Taniguchi T, Kiso Y, Yoshimoto K, Agatsuma T, Koide-Yoshida S, Iguchi-Ariga SM, Shimohama S, Ariga H (2006) PARK7 DJ-1 protects against degeneration of nigral dopaminergic neurons in Parkinson's disease rat model. Neurobiol Dis 24:144-158

Lee JM, Shih AY, Murphy TH, Johnson JA (2003) NF-E2-related factor-2 mediates neuroprotection against mitochondrial complex I inhibitors and increased concentrations of intracellular calcium in primary cortical neurons. J Biol Chem 278:37948-37956

Lev N, Ickowicz D, Melamed E, Offen D (2008) Oxidative insults induce DJ-1 upregulation and redistribution: implications for neuroprotection. Neurotoxicology 29:397-405

Lo SC, Hannink M (2006) PGAM5, a Bcl-XL-interacting protein, is a novel substrate for the redox-regulated Keap1-dependent ubiquitin ligase complex. J Biol Chem 281:37893-37903

Lo SC, Hannink M (2008) PGAM5 tethers a ternary complex containing Keap1 and Nrf2 to mitochondria. Exp Cell Res 314:1789-1803

Lotharius J, Falsig J, van BJ, Payne S, Dringen R, Brundin P, Leist M (2005) Progressive degeneration of human mesencephalic neuron-derived cells triggered by dopamine-dependent oxidative stress is dependent on the mixed-lineage kinase pathway. J Neurosci 25:6329-6342

Lu W, Karuppagounder SS, Springer DA, Allen MD, Zheng L, Chao B, Zhang Y, Dawson VL, Dawson TM, Lenardo M (2014) Genetic deficiency of the mitochondrial protein PGAM5 causes a Parkinson's-like movement disorder. Nat Commun 5:4930 
McAdory BS, Van Eldik LJ, Norden JJ (1998) S100B, a neurotropic protein that modulates neuronal protein phosphorylation, is upregulated during lesion-induced collateral sprouting and reactive synaptogenesis. Brain Res 813:211-217

Mendieta L, Bautista E, Sanchez A, Guevara J, Herrando-Grabulosa M, Moran J, Martinez R, Aguilera J, Limon ID (2012) The C-terminal domain of the heavy chain of tetanus toxin given by intramuscular injection causes neuroprotection and improves the motor behavior in rats treated with 6-hydroxydopamine. Neurosci Res 74:156-167

Moore DJ, Zhang L, Troncoso J, Lee MK, Hattori N, Mizuno Y, Dawson TM, Dawson VL (2005) Association of DJ-1 and parkin mediated by pathogenic DJ-1 mutations and oxidative stress. Hum Mol Genet 14:71-84

Niranjan R (2014) The role of inflammatory and oxidative stress mechanisms in the pathogenesis of Parkinson's disease: focus on astrocytes. Mol Neurobiol 49:28-38

Ouyang M, Shen X (2006) Critical role of ASK1 in the 6-hydroxydopamine-induced apoptosis in human neuroblastoma $\mathrm{SH}-$ SY5Y cells. J Neurochem 97:234-244

Pickrell AM, Youle RJ (2015) The roles of PINK1, Parkin, and mitochondrial fidelity in Parkinson's disease. Neuron 85:257-273

Raptis A, Torrejon-Escribano B, de Aranda IG, Blasi J (2005) Distribution of synaptobrevin/VAMP 1 and 2 in rat brain. J Chem Neuroanat 30:201-211

Reijneveld JC, Taphoorn MJ, Hoogenraad TU, van GJ (1997) Severe but transient parkinsonism after tetanus vaccination. J Neurol Neurosurg Psychiatry 63:258

Scarffe LA, Stevens DA, Dawson VL, Dawson TM (2014) Parkin and PINK1: much more than mitophagy. Trends Neurosci 37:315-324

Schildknecht S, Poltl D, Nagel DM, Matt F, Scholz D, Lotharius J, Schmieg N, Salvo-Vargas A, Leist M (2009) Requirement of a dopaminergic neuronal phenotype for toxicity of low concentrations of 1-methyl-4-phenylpyridinium to human cells. Toxicol Appl Pharmacol 241:23-35

Scholz D, Poltl D, Genewsky A, Weng M, Waldmann T, Schildknecht S, Leist M (2011) Rapid, complete and large-scale generation of post-mitotic neurons from the human LUHMES cell line. J Neurochem 119:957-971

Schroeter ML, Sacher J, Steiner J, Schoenknecht P, Mueller K (2013) Serum S100B represents a new biomarker for mood disorders. Curr Drug Targets 14:1237-1248

Sekine S, Kanamaru Y, Koike M, Nishihara A, Okada M, Kinoshita H, Kamiyama M, Maruyama J, Uchiyama Y, Ishihara N, Takeda K, Ichijo H (2012) Rhomboid protease PARL mediates the mitochondrial membrane potential loss-induced cleavage of PGAM5. J Biol Chem 287:34635-34645

Shih AY, Imbeault S, Barakauskas V, Erb H, Jiang L, Li P, Murphy TH (2005) Induction of the Nrf2-driven antioxidant response confers neuroprotection during mitochondrial stress in vivo. J Biol Chem 280:22925-22936

Shin OH (2014) Exocytosis and synaptic vesicle function. Compr Physiol 4:149-175
Stepkowski TM, Kruszewski MK (2011) Molecular cross-talk between the NRF2/KEAP1 signaling pathway, autophagy, and apoptosis. Free Radic Biol Med 50:1186-1195

Takeda K, Komuro Y, Hayakawa T, Oguchi H, Ishida Y, Murakami S, Noguchi T, Kinoshita H, Sekine Y, Iemura S, Natsume T, Ichijo H (2009) Mitochondrial phosphoglycerate mutase 5 uses alternate catalytic activity as a protein serine/threonine phosphatase to activate ASK1. Proc Natl Acad Sci USA 106: 12301-12305

Tanaka K, Miyake Y, Fukushima W, Sasaki S, Kiyohara C, Tsuboi Y, Yamada T, Oeda T, Miki T, Kawamura N, Sakae N, Fukuyama H, Hirota Y, Nagai M (2010) Active and passive smoking and risk of Parkinson's disease. Acta Neurol Scand 122:377-382

Temburni MK, Rosenberg MM, Pathak N, McConnell R, Jacob MH (2004) Neuronal nicotinic synapse assembly requires the adenomatous polyposis coli tumor suppressor protein. J Neurosci 24:6776-6784

Venugopal R, Jaiswal AK (1996) Nrf1 and Nrf2 positively and c-Fos and Fra1 negatively regulate the human antioxidant response element-mediated expression of $\mathrm{NAD}(\mathrm{P}) \mathrm{H}$ :quinone oxidoreductase1 gene. Proc Natl Acad Sci USA 93:14960-14965

Vos PE, Lamers KJ, Hendriks JC, van HM, Beems T, Zimmerman C, van GW, de RH, Biert J, Verbeek MM (2004) Glial and neuronal proteins in serum predict outcome after severe traumatic brain injury. Neurology 62:1303-1310

Wang Z, Jiang H, Chen S, Du F, Wang X (2012) The mitochondrial phosphatase PGAM5 functions at the convergence point of multiple necrotic death pathways. Cell 148:228-243

Wu H, Xue D, Chen G, Han Z, Huang L, Zhu C, Wang X, Jin H, Wang J, Zhu Y, Liu L, Chen Q (2014) The BCL2L1 and PGAM5 axis defines hypoxia-induced receptor-mediated mitophagy. Autophagy 10:1712-1725

Xu Y, Fang F, Miriyala S, Crooks PA, Oberley TD, Chaiswing L, Noel T, Holley AK, Zhao Y, Kiningham KK, Clair DK, Clair WH (2013) KEAP1 is a redox sensitive target that arbitrates the opposing radiosensitive effects of parthenolide in normal and cancer cells. Cancer Res 73:4406-4417

Yamamoto H, Ida T, Tsutsuki H, Mori M, Matsumoto T, Kohda T, Mukamoto M, Goshima N, Kozaki S, Ihara H (2012) Specificity of botulinum protease for human VAMP family proteins. Microbiol Immunol 56:245-253

Yokota T, Sugawara K, Ito K, Takahashi R, Ariga H, Mizusawa H (2003) Down regulation of DJ-1 enhances cell death by oxidative stress, ER stress, and proteasome inhibition. Biochem Biophys Res Commun 312:1342-1348

Zhang L, Ren X, Alt E, Bai X, Huang S, Xu Z, Lynch PM, Moyer MP, Wen XF, Wu X (2010) Chemoprevention of colorectal cancer by targeting APC-deficient cells for apoptosis. Nature 464:1058-1061

Zigmond MJ, Abercrombie ED, Berger TW, Grace AA, Stricker EM (1990) Compensations after lesions of central dopaminergic neurons: some clinical and basic implications. Trends Neurosci $13: 290-296$ 